\title{
Evaluation of the Physicochemical Parameters of Functional Whey Beverages
}

\author{
Aistè Kabašinskienè ${ }^{1 *}$, Algirdas Liutkevičius ${ }^{2}$, Dalia Sekmokiené $\dot{1}^{1}$ \\ Gintare Zaborskiene $\dot{e}^{1,2}$ and Jüraté Šlapkauskaité ${ }^{1}$ \\ ${ }^{1}$ Lithuanian University of Health Sciences, Department of Food Safety and Quality, Tilzes Str. 18, \\ LT-47181 Kaunas, Lithuania \\ ${ }^{2}$ Kaunas University of Technology, Food Institute, Taikos Av. 92, LT-51180 Kaunas, Lithuania
}

Received: June 10, 2014

Accepted: October 22, 2014

\begin{abstract}
Summary
The objective of this study is to determine the impact of the key technological parameters on the quality indices of functional beverages produced from whey and enriched with $0.2 \%$ of cold-pressed flaxseed oil, rich in $\omega-3$ fatty acids. The amount of fatty acids, peroxide and anisidine values, fatty acidity, sedimentation and sensory parameters of whey beverages were estimated. It was found that the addition of flaxseed oil affected the sensory, physical and chemical properties of the beverages. High quantities of oleic and $\alpha$-linolenic fatty acids (18.97 and $54.82 \%$, respectively) and negligible amounts of palmitic and myristic acids ( 4.79 and $0.04 \%$, respectively) were found in the product. On the basis of the obtained results, the beverages from whey enriched with flaxseed oil had a favourable ratio of $n-6 / n-3$ polyunsaturated fatty acids and atherogenic and thrombogenic indices. The addition of a stabiliser and the pasteurisation of whey beverages with flaxseed oil did not affect the sensory parameters and the acidity of the products. The highest peroxide value $\left(2.36 \mathrm{meq} \mathrm{O}_{2} / \mathrm{kg}\right)$ and acidity $(0.34 \%)$ were found in the samples with $\mathrm{pH}=4.0$ after 30-day storage at $(6 \pm 1){ }^{\circ} \mathrm{C}$. A strong negative correlation was estimated between the amount of polyunsaturated fatty acids and anisidine value $(\mathrm{R}=-0.871 ; \mathrm{p}<0.05)$, peroxide value $(R=-0.728 ; \mathrm{p}<0.05)$ and fatty acidity $(R=-0.948 ; \mathrm{p}<0.05)$.
\end{abstract}

Key words: whey, flaxseed oil, beverages, $\omega-3$ fatty acids, oxidation

\section{Introduction}

Whey is a by-product of the manufacture of cheese or curd. It has been used in the food industry for about 20 years; however, interest in the use of whey has recently increased owing to its high nutritional and functional properties. Whey contains a large quantity of nutritionally rich components (1). Biologically active whey proteins, minerals, water-soluble vitamins and lactose remain in whey after processing (2). Many easily digestible bioactive components derived from whey are under study for their ability to offer specific health benefits $(3,4)$.

Whey proteins are of special importance. They represent about $20 \%$ of milk proteins and are characterised by a high digestibility, amino acid score and contain high percentage of branched-chain amino acids (BCAAs), such as leucine, isoleucine and valine. High amounts of these amino acids have long been popular in the industry as a muscle-building supplement for athletes during intensive exercise. Consequently, whey proteins provide excellent nutritional value in foods formulated for kids, adults and elderly people, or as supplements for body health maintenance. $\beta$-Lactoglobulin ( $\beta$-Lg) and $\alpha$-lactalbumin $(\alpha$-La) are of the greatest importance and compose more than a half of total whey proteins ( $50 \% \beta-\operatorname{Lg}$ and $12 \% \alpha$-La); the rest are: immunoglobulins $10 \%$, serum albumin $5 \%$ and proteose peptones $0.23 \%$, lactoferrin (LF) and lactoperoxydase (LP) (1). 
Whey proteins as functional ingredients reflect a wide range of potential therapeutic applications. Individual whey protein components and their peptide fragments stimulate the immune system, anticarcinogenic activity and other metabolic features (5). Graf et al. (6) identified 25 intervention trials examining chronic and/or acute effects of whey protein supplementation on lipid and glucose metabolism, blood pressure, vascular function and on the musculoskeletal system. However, the evaluation of the efficacy of bioactive proteins/peptides in animal model and human clinical studies is needed to fully substantiate their role (7).

The nutritional and functional properties of whey are of great significance for the formulation of food products. Whey and whey-derived products, apart from being nutritional ingredients in various foods, can also be used as functional ingredients providing flavour, texture, colour and aeration properties in a variety of foods (1). Whey proteins can be used as supplements as well as food ingredients due to their unique effect on food texture $(8,9)$. Their concentrates are used in the processing of meat and milk products. Soluble whey proteins are used in the manufacture of dietary products. Acid whey is useful for making milk desserts and other confectionary products. Hydrolysed condensed whey is important in the industries of cheese (ricotta, mizithra), confectionary and bread baking, while whey and egg protein concentrate is produced as well (1). Fresh whey is also used as a stock for acidic, hydrolysed and pasteurised drinks (kvass, fizzy drinks, koumiss, etc.), enriched with different additives (sugar, raisins, vegetable oil, syrups, fruit juices, aromatic substances, stabilisers, milk proteins and $\omega-3$ polyunsaturated fatty acids (PUFA)) which are added before pasteurisation (2). Introducing a hydrolysed whey protein concentrate with antihypertensive peptides into beverages appears to create an excellent link between food science and therapeutic nutrition (7).

The physiological function of PUFA is related to heart and vascular diseases. The $\omega-3$ fatty acids are known to be essential for proper development and functioning of brain, retina and nervous system (10). Due to the low current intake levels of $\omega-3$ fatty acids through diet, there is a need for fortified products that can deliver substantial amounts of $\omega-3$ fatty acids (11).

Flaxseed oil is rich in unsaturated fatty acids, recognized as one of the greatest sources of $\omega-3$ fatty acids in nature and having a positive effect on human health. Their role in reducing the risk of cardiovascular diseases has been increasingly recognized $(12,13)$. As only three of the saturated fatty acids (SFA) are in fact hypercholesteremic, the PUFA/SFA ratio is not a particularly suitable measure of the atherogenicity or thrombogenicity of the foods (14). The ratio of oleic to palmitic acid (monounsaturated fatty acids (MUFA/SFA) in dietary fats has a regulatory influence on certain thrombogenic and fibrinolytic markers during the postprandial state in healthy subjects (15). Consequently, lipid quality indicators that depend on the relative contents of particular groups of fatty acids are atherogenic (AI) and thrombogenic (TI) indices, indicating the global dietetic quality of lipids.

In order to increase the assortment of functional beverages, whey can be used as a source of proteins, and flax- seed oil as a source of $\omega-3$ fatty acids. Thus, the aim of this study is to create a functional whey beverage enriched with $\omega-3$ fatty acids and to evaluate its quality.

\section{Materials and Methods}

\section{Materials}

Whey beverages containing cold-pressed flaxseed oil with dominant $\omega-3 \alpha$-linolenic fatty acid (C18:3n-3) were used in the experiment. The production of beverages from fresh sour whey, obtained in the manufacture of curd, was done at the technological laboratory of the Food Institute at Kaunas University of Technology, Lithuania, and was approved by milk enterprises: JSC Rivona (Vilnius, Lithuania) and JSC Venitas (Vilnius, Lithuania).

The whey was produced from pasteurised milk, using a starter consisting of mesophilic cultures of Lactococcus lactis ssp. cremoris, Lactococcus lactis ssp. lactis, Leuconostoc mesenteroides ssp. cremoris and Lactococcus lactis ssp. diacetylactis (FD-DVS Flora Danica, Chr. Hansen, Hørsholm, Denmark), characterised by fast production of lactic and citric acids. The fraction of starter added to the milk was $0.015 \%$. The composition of fresh whey was as follows (in \%): dry matter 6.42, lactose 4.4 , protein 0.53 and fat $0.05, \mathrm{pH}=3.8-4.2$.

The model system of whey and flaxseed oil was made by enrichment of the whey with $0.2 \%$ of flaxseed oil (JSC Aletovis, Šakiai, Lithuania) containing high amounts of $\alpha$-linolenic (58\%), linoleic (14\%) and oleic (19\%) fatty acids and by the addition of a stabiliser No 5834 (Palsgaard Industry A/S, Juelsminde, Denmark) consisting of cellulose and pectin in equal parts. The stabiliser was used to prevent precipitation of whey protein in beverages during their thermal treatment. Before its introduction into beverages, the dry mix of stabiliser and sugar in a ratio of 1:10 was dissolved in hot water $\left((70 \pm 5){ }^{\circ} \mathrm{C}\right)$. The content of sugar in final beverages was $7.0 \%$. The processed beverages, pasteurised at $(85 \pm 2){ }^{\circ} \mathrm{C}$ and cooled to $(10 \pm 2)$ ${ }^{\circ} \mathrm{C}$, were filled into 0.5 -litre clear glass bottles and stored in refrigerator at $(6 \pm 1){ }^{\circ} \mathrm{C}$ for 30 days for further analyses.

\section{Methods}

The sensory parameters (colour, odour and taste) of the prepared whey beverages were evaluated by a panel of eight judges following a five-point hedonic scale (where 1 point means bad, 2 satisfactory, 3 good, 4 very good and 5 excellent) on the 1st, 14th and 30th day of storage. The panellists were selected and instructed according to ISO 8586:2012 (16). The samples were served to the panellists in one session. The acceptability of the beverages was rated based on a scale of points ranging from 'like extremely' to 'dislike extremely' according to LST ISO 4121:2004 (17).

The fatty acid oxidation level was established by peroxide (ISO 3960:2007 (18)) and anisidine (LST ISO 6885: 2000 (19)) values. The acidity (LST EN ISO 660:2009 (20)) was measured with Calimatic pH meter 766 (Knick Elektronische Messgeräte GmbH \& Co. KG, Berlin, Germany).

Viscosity was analysed with Höppler viscometer KF10 (RheoTec Messtechnik GmbH, Ottendorf-Okrilla, Germa- 
ny). The mixture was emulsified by using laboratory mixer (IKA, Labortechnik, Staufen, Germany), at the revolution of $225 \mathrm{~s}^{-1}$ and treatment time of $5 \mathrm{~min}$.

Sedimentation of prepared beverages was monitored according to Towler (21). It was done by centrifugation at $3000 \times g$ for $20 \mathrm{~min}$ at ambient temperature. Sediment was calculated as a percentage of the total fluid mass according to the following equation:

\section{Sediment in tube $=$}

(sediment after $24 \mathrm{~h} /$ fluid total mass) 100

The mass fraction of fatty acids in processed whey beverages with flaxseed oil was determined with gas chromatography method, using a flame ionization detector. Samples for analysis were prepared according to the standard LST EN ISO 12966-2:2011 (22). Fatty acids were methylated using anhydrous $\mathrm{KOH}$ methanol solution. Chromatographic analysis of fatty acid methyl esters was performed using a gas chromatograph Shimadzu GC-2010 (Shimadzu Corporation, Tokyo, Japan), fitted with flame ionization detector. Methyl esters of fatty acids were separated on a BPX-70, column length $120 \mathrm{~m}$ (Part No 054624, Scientific Instrument Services, Inc., Ringoes, NJ, USA) following the methodology established in LST EN ISO 15304:2003/AC:2005 (23).

The analytical conditions were: column temperature of $60{ }^{\circ} \mathrm{C}$ for $2 \mathrm{~min}$, then $13{ }^{\circ} \mathrm{C} / \mathrm{min}$ to $230{ }^{\circ} \mathrm{C}$, maintaining the temperature for $45 \mathrm{~min}$, carrier gas was nitrogen, injector temperature was held at $250{ }^{\circ} \mathrm{C}$, and flame ionization detector temperature was held at $270{ }^{\circ} \mathrm{C}$.

For the identification of fatty acids, 47885-U Supel$\mathrm{Co}^{\circledR} 37$ Component FAME Mix (Sigma-Aldrich Co.) was used. The peaks were identified by comparison of their retention times with those of the standard fatty acid methyl esters. The relative fraction of each fatty acid was expressed as the percentage of the sum of total fatty acids.

Lipid quality indices, i.e. atherogenic index (AI) and thrombogenic index (TI), were calculated according to Ulbricht and Southgate (14) and Jankowska et al. (24) using the following formulae:

$$
\begin{gathered}
\mathrm{AI}=[\mathrm{C} 12: 0+(4 \cdot \mathrm{C} 14: 0)+\mathrm{C} 16: 0] / \\
/[\mathrm{n}-6 \mathrm{PUFA}+\mathrm{n}-3 \mathrm{PUFA}+\mathrm{MUFA}]
\end{gathered}
$$

$$
\begin{gathered}
\text { TI }=[\mathrm{C} 14: 0+\mathrm{C} 16: 0+\mathrm{C} 18: 0] /[(0.5 \cdot \mathrm{MUFA})+ \\
+(0.5 \cdot n-6 \text { PUFA })+(3 \cdot n-3 \text { PUFA })+n-3 / n-6 \text { PUFA }]
\end{gathered}
$$

\section{Statistical analysis}

All the tests were repeated three times. Data were processed using descriptive and statistical analysis methods of SPSS statistical package (SPSS Inc., v. 17, IBM Corporation, Armonk, New York, NY, USA). The number of variables $(N)$, arithmetic averages, their standard deviations (S.D.) and the minimum ( $\mathrm{min}$ ) and maximum (max) values were calculated using descriptive analysis. Statistical processing of scores obtained by sensory evaluation, was done using Excel 2007 (Microsoft Corporation, Redmond, WA, USA) and paired $t$-test. For all statistical analyses $\mathrm{p} \leq 0.05$ was considered statistically significant.

\section{Results and Discussion}

As stabiliser was used in processing of the whey beverages with added flaxseed oil, the influence of stabiliser on the sensory and physicochemical properties of prepared beverages was analysed. Table 1 shows that the impact of stabiliser on the viscosity and taste of the beverages was statistically significant $(\mathrm{p}<0.05)$. However, the added mass fraction of the stabiliser had no effect on colour, odour and active acidity of the beverages.

The optimal mass fraction of the stabiliser that ensured the stability of whey protein phase during heat treatment and provided the most acceptable taste of beverages was $0.2 \%$. The viscosity of the beverages after adding $0.2 \%$ of the stabiliser increased by $3.6 \mathrm{mPa} \cdot \mathrm{s}$ compared with a product without a stabiliser. The taste of the beverages with stabiliser was more acceptable than the watery taste of the product without a stabiliser. This mass fraction of the stabiliser also ensured the absence of sedimentation.

The $\omega-3$ fatty acids are susceptible to oxidation due to the double bonds present in the molecular structure. Therefore, it is important to evaluate the quantitative

\begin{tabular}{|c|c|c|c|c|c|c|}
\hline \multirow{2}{*}{ Indicator } & \multicolumn{6}{|c|}{$w($ stabiliser $) / \%$} \\
\hline & 0 & 0.1 & 0.2 & 0.3 & 0.4 & 0.5 \\
\hline \multicolumn{7}{|l|}{ Sensory parameter/score: } \\
\hline colour $(0-5)$ & 5 & 4.9 & 5 & 4.9 & 4.6 & 4.5 \\
\hline odour $(0-5)$ & 5 & 4.9 & 5 & 4.8 & 4.8 & 4.7 \\
\hline taste $(0-5)$ & $4.3^{*}$ & $4.2^{*}$ & $4.3^{*}$ & $4.2^{*}$ & $3.8^{*}$ & $3.6^{*}$ \\
\hline \multicolumn{7}{|l|}{ Active acidity, $\mathrm{pH}$ : } \\
\hline before pasteurisation & $3.82 \pm 0.01$ & $3.81 \pm 0.01$ & $3.83 \pm 0.02$ & $3.81 \pm 0.01$ & $3.82 \pm 0.02$ & $3.83 \pm 0.01$ \\
\hline after pasteurisation & $3.63 \pm 0.02$ & $3.67 \pm 0.02$ & $3.72 \pm 0.01$ & $3.71 \pm 0.02$ & $3.77 \pm 0.01$ & $3.82 \pm 0.02$ \\
\hline after 24-hour storage & $4.02 \pm 0.01$ & $4.14 \pm 0.02$ & $4.07 \pm 0.01$ & $4.06 \pm 0.03$ & $4.11 \pm 0.02$ & $4.19 \pm 0.01$ \\
\hline Viscosity at $20^{\circ} \mathrm{C} /(\mathrm{mPa} \cdot \mathrm{s})$ & $(1.20 \pm 0.04)^{* *}$ & $(3.40 \pm 0.03)^{*}$ & $(4.80 \pm 0.02)^{*}$ & $(6.80 \pm 0.01)^{*}$ & $(9.40 \pm 0.03)^{*}$ & $(9.90 \pm 0.02)^{* *}$ \\
\hline Sedimentation $/ \%$ & 0.060 & 0.055 & NS & NS & NS & NS \\
\hline
\end{tabular}
changes of fatty acids of flaxseed oil-enriched beverages during storage. Table 2 shows the quantitative changes of

Table 1. Influence of stabiliser on sensory and physicochemical properties of whey beverages with added flaxseed oil

Values for $\mathrm{pH}$ and viscosity are expressed as mean \pm S.D.; differences between columns: ${ }^{*} \mathrm{p}<0.05,{ }^{* *} \mathrm{p}<0.01$; NS=no sedimentation 
Table 2. Quantitative changes of fatty acids in whey beverages with added flaxseed oil during storage at $(6 \pm 1)^{\circ} \mathrm{C}$

\begin{tabular}{|c|c|c|c|}
\hline \multirow{2}{*}{ Fatty acid } & \multicolumn{3}{|c|}{$w(\mathrm{FA}) /(\mathrm{g} / 100 \mathrm{~g})$} \\
\hline & 1st day (directly after making) & 14th day of storage & 30th day of storage \\
\hline Saturated fatty acids & $8.90 \pm 0.09$ & $9.06 \pm 0.09$ & $8.93 \pm 0.08$ \\
\hline Lauric (C12:0) & 0 & 0 & 0 \\
\hline Myristic (C14:0) & $0.04 \pm 0.01$ & $0.04 \pm 0.01$ & $0.04 \pm 0.01$ \\
\hline Palmitic (C16:0) & $4.79 \pm 0.04$ & $4.92 \pm 0.04$ & $4.98 \pm 0.03$ \\
\hline Margaric (C17:0) & $0.09 \pm 0.01$ & $0.09 \pm 0.01$ & $0.05 \pm 0.01$ \\
\hline Stearic (C18:0) & $3.83 \pm 0.02$ & $3.85 \pm 0.02$ & $3.81 \pm 0.02$ \\
\hline Arachidic (C20:0) & $0.15 \pm 0.01$ & $0.16 \pm 0.01$ & $0.15 \pm 0.01$ \\
\hline Oleic (C18:1 (cis-isomer)) & $18.97 \pm 0.09$ & $19.03 \pm 0.09$ & $19.14 \pm 0.08$ \\
\hline Eicosenoic (C20:1) & $0.18 \pm 0.02$ & $0.15 \pm 0.01$ & $0.2 \pm 0.01$ \\
\hline Erucic (C22:1) & $0.04 \pm 0.01$ & $0.05 \pm 0.01$ & $0.06 \pm 0.01$ \\
\hline Linoleic (C18:2n-6) & $16.58 \pm 0.07$ & $16.37 \pm 0.06$ & $16.37 \pm 0.06$ \\
\hline$\alpha$-Linolenic (C18:3n-3) & $54.8 \pm 0.2$ & $54.7 \pm 0.2$ & $54.6 \pm 0.1$ \\
\hline Polyunsaturated fatty acids & $71.5 \pm 0.3$ & $71.2 \pm 0.2$ & $71.1 \pm 0.2$ \\
\hline MUFA & $19.2 \pm 0.1$ & $19.2 \pm 0.1$ & $19.4 \pm 0.1$ \\
\hline PUFA & $71.5 \pm 0.3$ & $71.2 \pm 0.2$ & $71.1 \pm 0.2$ \\
\hline n-6/n-3 PUFA ratio & 0.30 & 0.30 & 0.30 \\
\hline $\mathrm{AI}$ & 0.05 & 0.06 & 0.06 \\
\hline TI & 0.04 & 0.05 & 0.05 \\
\hline
\end{tabular}

Values for fatty acid mass fraction are expressed as mean \pm S.D.; PUFA=polyunsaturated fatty acids, MUFA=monounsaturated fatty acids, $\mathrm{AI}=$ atherogenic index, $\mathrm{TI}=$ thrombogenic index

different fatty acids found in whey beverages with flaxseed oil at $(6 \pm 1){ }^{\circ} \mathrm{C}$.

The main PUFA of the flaxseed oil is $\alpha$-linolenic fatty acid C18:3. Its determined mass fraction in the fresh oil was $54.8 \%$. It is known that the increase of human cholesterol levels is influenced by the amount of fatty acids, in this case, myristic, palmitic and lauric acids have the highest impact. The data presented in Table 2 show that there were $4.79 \%$ of palmitic acid and $0.04 \%$ of myristic acid detected in fresh flaxseed oil samples; however, lauric acid was not detected. The fresh whey beverages also contained $18.97 \%$ of physiologically beneficial oleic acid. The levels of $\omega-6$ fatty acids, including linoleic and arachidonic acids, were lower: 16.58 and $0.06 \%$ respectively. The composition of fatty acids showed that PUFAs were predominant and that the ratio of n-6/n-3 was favourable (0.3).

No significant quantitative changes of fatty acids were detected when the beverages were stored for 14 and 30 days at $(6 \pm 1)^{\circ} \mathrm{C}$. Such results could be the consequence of a low storage temperature and especially of the $\mathrm{pH}$ of the medium, as lipases are known to be passive in acid medium.

From a nutritional viewpoint, it can be assumed that the prepared beverages are a good source of whey proteins and $\omega-3$ fatty acids (containing more than $70 \%$ of PUFAs) and according to the results, no oxidation took place during 30 days at refrigeration temperature. Similar results were obtained by Gad et al. (25), who analysed the stability of whey and mango beverages at refrigerator temperature for 15 days.

Incorporation of flaxseed oil into beverages is particularly attractive for development of beverages with specific health advantages. The flaxseed oil was reported to reduce susceptibility to cardiovascular diseases and hypertension (26). After the evaluation of fatty acid composition in whey beverages with flaxseed oil and calculation of $\mathrm{AI}$ and TI indices, it was found that $\mathrm{AI}$ and TI values were low, which indicates high quantities of fatty acids with antiatherogenic properties in the oil. These indices demonstrate the relationship between fatty acids in food and their contribution to the prevention of coronary diseases (27). Atherogenic index shows the relationship between the sum of the main saturated and that of the main unsaturated fatty acids, the former being considered proatherogenic (favouring the adhesion of lipids to cells of the immunological and circulatory systems), and the latter antiatherogenic (inhibiting the aggregation of plaque and diminishing the levels of esterified fatty acids, cholesterol and phospholipids by preventing the appearance of micro- and macrocoronary diseases). Thrombogenic index indicates the tendency to form clots in the blood vessels. This is defined as the relationship between the fatty acids with prothrombogenic (saturated) and antithrombogenic (MUFAs, n-6 PUFAs and n-3 PUFAs) properties $(14,28)$. However, in our case, the atherogenic and thrombogenic indices of prepared whey beverages with flaxseed oil were lower than in the muscles (intramuscular lipids) of different domestic and wild animal species (29), in fish and fish products (30-32) and in olive oil (14).

The oxidation processes of fatty acids in the beverages and their dependence on the active acidity were analysed as well. The fatty acids were analysed directly after making of beverages (1st day) and after storage for 14 and 30 days at $(6 \pm 1){ }^{\circ} \mathrm{C}$ (Table 3$)$. 
Table 3. Dependence of the oxidation and sensory parameters of whey beverages with added flaxseed oil on the storage time at $(6 \pm 1)^{\circ} \mathrm{C}$

\begin{tabular}{|c|c|c|c|c|c|c|}
\hline$\frac{t \text { (storage) }}{\text { day }}$ & $\mathrm{AV}$ & $\frac{\mathrm{PV}}{\mathrm{meq} \mathrm{O}_{2} / \mathrm{kg}}$ & $\frac{\text { Fatty acidity }}{\%}$ & $\begin{array}{c}\text { Colour } \\
(0-5)\end{array}$ & $\begin{array}{l}\text { Odour } \\
(0-5)\end{array}$ & $\begin{array}{l}\text { Taste } \\
(0-5)\end{array}$ \\
\hline 1 & $0.65 \pm 0.05$ & $(1.46 \pm 0.06)^{*}$ & $0.33 \pm 0.02$ & 5 & 5 & 4.3 \\
\hline 14 & $0.70 \pm 0.06$ & $(1.47 \pm 0.05)^{*}$ & $0.33 \pm 0.02$ & 5 & 4.7 & 4.2 \\
\hline 30 & $0.80 \pm 0.04$ & $(1.56 \pm 0.05)^{*}$ & $0.34 \pm 0.02$ & 5 & 4.5 & 4.0 \\
\hline $\begin{array}{l}\text { Freshly pressed } \\
\text { flaxseed oil }\end{array}$ & $0.50 \pm 0.06$ & $(1.90 \pm 0.05)^{*}$ & $0.11 \pm 0.01$ & & & \\
\hline
\end{tabular}

Values for $\mathrm{AV}, \mathrm{PV}$ and fatty acidity are expressed as mean \pm S.D.; differences between rows: ${ }^{\mathrm{p}} \mathrm{p}<0.05$; $\mathrm{AV}=$ anisidine value, $\mathrm{PV}=$ peroxide value

After storage of the beverages at refrigeration temperature for 30 days, no statistically significant changes were detected in the oxidation indices (anisidine value (AV) and fatty acidity), although the tendency of increase of peroxide value (PV) was observed. After 30 days of storage, PV reached $1.56(\mathrm{p}<0.05)$; however, the maximum limit established by the Order of the Minister of Agriculture of Lithuania No 155, 1999 was not exceeded.

A medium positive correlation was found between the AV and PV $(R=0.651 ; p<0.05)$. With the increased AV, the fatty acidity also increased $(\mathrm{R}=0.677 ; \mathrm{p}<0.05)$. A strong positive correlation was determined between the PV and fatty acidity $(R=0.900 ; p<0.05)$ during 30 days of storage as well.

During storage for 30 days, the amount of PUFA decreased and the PV and AV increased as a result of weak oxidation process. A strong negative correlation was observed between the amount of PUFA and the anisidine value $(\mathrm{R}=-0.871 ; \mathrm{p}<0.05)$, peroxide value $(\mathrm{R}=-0.728 ; \mathrm{p}<0.05)$ and the fatty acidity $(\mathrm{R}=-0.948 ; \mathrm{p}<0.05)$. To summarise, we can conclude that whey beverages containing flaxseed oil remain stable at $\mathrm{pH}=4.0$ and oxidation after storage for 30 days at $(6 \pm 1)^{\circ} \mathrm{C}$ is weak.

Sensory parameters are the first attributes to judge the acceptability and overall quality of beverages by consumers. It was found that sensory parameters of the beverages remained acceptable during all 30 days of storage: values of the colour did not change and values of the odour and taste slightly decreased. Similar results were obtained in newly prepared whey beverages analysed by Gad et al. (25). The sensory evaluation study suggests that whey beverages with flaxseed oil retain the overall acceptability with good sensory quality and can be successfully stored at refrigeration temperature.

\section{Conclusions}

The analysis showed that functional beverages from whey enriched with flaxseed oil could be produced in milk industry. The use of flaxseed oil containing $\alpha$-linolenic fatty acid (54.8\% of total fatty acids) and a stabiliser $(0.2 \%)$ had the most positive impact on the sensory properties and physicochemical parameters of functional whey beverages at $\mathrm{pH}=4.0$ during 30 days of testing period. Enrichment of beverages with flaxseed oil may provide the required components for optimum health. Whey beverages as a source of products with low atherogenic index could be useful for human health and are especially rec- ommended for the prevention of cardiovascular diseases. The consumption of whey beverages with flaxseed oil as a product rich in n-3 PUFA may considerably increase in human diets nowadays.

\section{Acknowledgements}

This research was funded by a grant from the Research Council of Lithuania (nr. SVE-08/2012).

\section{References}

1. Jain S, Gupta R, Jain S. Development of low cost nutritional beverage from whey. J Environ Sci Toxicol Food Technol. 2013;5:73-88.

http://dx.doi.org/10.9790/2402-0517388

2. Sekmokienė D, Šernienė L, Liutkevičius A. Innovative recasting methods of milk, buttermilk and whey. Food Chem Tech. 2008;42:89-92 (in Lithuanian).

Aleph ID: KTU02-000042879

3. Frid AH, Nilsson M, Holst JJ, Björck IM. Effect of whey on blood glucose and insulin responses to composite breakfast and lunch meals in type 2 diabetic subjects. Am J Clin Nutr. 2005;82:69-75.

4. Ha E, Zemel MB. Functional properties of whey, whey components, and essential amino acids: mechanisms underlying health benefits for active people. J Nutr Biochem. 2003;14: 251-8.

http://dx.doi.org/10.1016/S0955-2863(03)00030-5

5. Gobetti M, Stepaniak L, DeAngelis M, Corsetti A, Cagno RD. Latent bioactive peptides in milk proteins: Proteolytic activation and significance in diary processing. Crit Rev Food Sci. 2002;42:223-39.

http://dx.doi.org/10.1080/10408690290825538

6. Graf S, Egert S, Heer M. Effects of whey protein supplements on metabolism: evidence from human intervention studies. Curr Opin Clin Nutr Metab Care. 2011;14:569-80. http://dx.doi.org/10.1097/MCO.0b013e32834b89da

7. Rhicha S, Radha C, Kaul P. Whey protein hydrolysate: Functional properties, nutritional quality and utilization in beverage formulation. Food Chem. 2007;101:1484-91.

http://dx.doi.org/10.1016/j.foodchem.2006.04.021

8. Siso MIG. The biotechnological utilization of cheese whey: a review. Bioresource Technol. 1996;57:1-11. http://dx.doi.org/10.1016/0960-8524(96)00036-3

9. Ji T, Haque ZU. Cheddar whey processing and source: I. Effect on composition and functional properties of whey protein concentrates. Int. J Food Sci Tech. 2003;38:453-61. http://dx.doi.org/10.1046/j.1365-2621.2003.00704.x

10. Ruxton C, Reed S, Simpson M, Millington K. The health benefits of omega-3 polyunsaturated fatty acids: a review of the evidence. J Hum Nutr Diet. 2004;17:449-59. http://dx.doi.org/10.1111/j.1365-277X.2004.00552.x 
11. Moore RL. Antioxidant protection of an $\omega-3$ fatty acid fortified dairy-based beverage [Master's thesis]. Blacksburg, VA; USA: Virginia Polytechnic Institute and State Univ. 2009.

12. Kuhn KR, Cunha RL, Flaxseed oil - Whey protein isolate emulsions: Effect of high pressure homogenization. J Food Eng. 2012;111:449-57. http://dx.doi.org/10.1016/j.jfoodeng.2012.01.016

13. Zhao G, Etherton TD, Martin KR, Gillies PJ, West SG, Kris-Etherton PM. Dietary $\alpha$-linolenic acid inhibits proinflammatory cytokine production by peripheral blood mononuclear cells in hypercholesterolemic subjects. Am J Clin Nutr. 2007; 85:385-91.

14. Ulbricht TLV, Southgate DAT. Coronary disease seven dietary factors. Lancet. 1991;338:985-92. http://dx.doi.org/10.1016/0140-6736(91)91846-M

15. Pacheco YM, Bermúdez B, López S, Abia R, Villar J, Muriana FJG. Ratio of oleic to palmitic acid is a dietary determinant of thrombogenic and fibrinolytic factors during the postprandial state in men. Am J Clin Nutr. 2006;84:342-9.

16. ISO 8586:2012. Sensory analysis - General guidelines for the selection, training and monitoring of selected assessors and expert sensory assessors. Geneva, Switzerland; 2012.

17. LST ISO 4121:2004. Guidelines for the use of quantitative response scales (ISO 4121:2003); 2004 (in Lithuanian).

18. ISO 3960:2007. Animal and vegetable fats and oils - Determination of peroxide value - Iodometric (visual) endpoint determination. Geneva, Switzerland; 2007.

19. LST ISO 6885:2000. Animal and vegetable fats and oils. Determination of anisidine value; 2000 (in Lithuanian).

20. LST EN ISO 660:2009. Animal and vegetable fats and oils Determination of acid value and acidity (ISO 660:2009); 2009 (in Lithuanian).

21. Towler C. Sedimentation in a cultured milk beverage. NZ J Dairy Sci Technol. 1984;19:205-11.

22. LST EN ISO 12966-2:2011. Animal and vegetable fats and oils - Gas chromatography of fatty acid methyl esters - Part 2: Preparation of methyl esters of fatty acids (ISO 12966-2:2011); 2011 (in Lithuanian).

23. LST EN ISO 15304:2003/AC:2005. Animal and vegetable fats and oils - Determination of the content of trans fatty acid isomers of vegetable fats and oils - Gas chromatographic method (ISO 15304:2002/Cor.1:2003); 2005.

24. Jankowska B, Zakęś Z, Źmijewski T, Szczepkowski M. Fatty acid profile of muscles, liver and mesenteric fat in wild and reared perch (Perca fluviatilis L.). Food Chem. 2010;118:764-8 http://dx.doi.org/10.1016/j.foodchem.2009.05.055

25. Gad AS, Emam WH, Mohamed GF, Sayd AF. Utilization whey in production of functional healthy beverage 'Wheymango beverages'. Am J Food Tech. 2013;8:133-48. http://dx.doi.org/10.3923/ajft.2013.133.148

26. Breslow JL. n-3 Fatty acids and cardiovascular disease. Am J Clin Nutr. 2006;83:1477-82.

27. Turan H, Sönmez G, Kaya Y. Fatty acid profile and proximate composition of the thorn-back ray (Raja clavata $\mathrm{L}$. 1758) from the Sinop coast in the Black Sea. Fisheries Sci. 2007;1:97-103. http://dx.doi.org/10.3153/jfscom.2007012

28. Senso L, Suarez MD, Ruiz-Cara T, Garcia-Gallego M. On the possible effects of harvesting season and chilled storage on the fatty acid profile of the fillet of farmed gilthead sea bream (Sparus aurata). Food Chem. 2007;101:298-307. http://dx.doi.org/10.1016/j.foodchem.2006.01.036

29. Razmaite V, Švirmickas J, Šiukščius A, Šveistienè R. Comparative characterization of fatty acid profiles in intramuscular lipids from different domestic and wild monogastric animal species. Vet Med Zoot. 2011;53:45-50.

30. Garaffo MA, Vassallo-Agius R, Nengas Y, Lembo E, Rando $R$, Maisano R, et al. Fatty acids profile, atherogenic (IA) and thrombogenic (IT) health lipid indices, of raw roe of blue fin tuna (Thunnus thynnus L.) and their salted product 'Bottarga'. Food Nutr Sci. 2011;2:736-43. http://dx.doi.org/10.4236/fns.2011.27101

31. Barra A, Garau VL, Dessi A, Sarais G, Ceretti E, Alorio M, et al. Chemical characterization and DNA tracking of Sardinian botargo by Mugil cephalus from different geographical origins. J Agric Food Chem. 2008;56:10847-52. http://dx.doi.org/10.1021/jf802363k

32. Scano P, Rosa A, Mereu S, Piras C, Atzeri A, Dessi MA. Multivariate fatty acid and fatty alcohol profile of mullet bottarga. Eur J Lipid Sci Tech. 2010;112:1369-74. http://dx.doi.org/10.1002/ejlt.201000321 